\title{
Efficiency of chemical protection of spring rape and mustard from rape blossom beetle
}

\author{
S. V. Stankevych¹, M. D. Yevtushenko1 , V. V. Vilna1', I. V. Zabrodina1', D. D. Yushchuk1, \\ L. Ya. Sirous', N. V. Lutytska1', O. A. Molchanova1, V. O. Melenti1', L. V. Golovan'1, I. V. Klymenko², \\ L. V. Zhukova', A. A. Poedinceva' ${ }^{1}$, O. V. Pismennyi³, O. V. Romanov', T. A. Romanova ${ }^{1}$ \\ 'V.V. Dokuchaev Kharkov National Agrarian University, v. Dokuchaevske, \\ Kharkiv region, 62483, Ukraine \\ ${ }^{2}$ V. Ya. Yuryev The Plant Production Institute of NAAS, Kharkiv, 61060, Ukraine \\ 3Mykolayiv National Agrarian University, Mykolayiv, 54020, Ukraine \\ E-mail: sergejstankevich1986@gmail.com.Tel.: +38-050-4000-985.
}

Received 10.10.2019 Accepted 11.2019

\begin{abstract}
One of the most dangerous pests of cabbage crops which can damage plants in the budding and flowering phases in all areas of their cultivation is a rape blossom beetle (Meligethes aeneus Fabricius, 1775). The pest is widespread throughout Ukraine; it causes significant damage to the crops every year and reduces the seed yields. It should be noted that the rape blossom beetle is not new to our country and as a pest of rape and other crops from the cabbage family has been mentioned since 1845, and a detailed description of its morphology, biology and ecology can be found in the works of the nineteenth century.

It is established that in the Eastern Forest-Steppe of Ukraine the first individuals of the rape blossom beetle appear on the flowering wild growing plants (first of all on dandelion and buttercup) when the average daily temperature exceeds $8{ }^{\circ} \mathrm{C}$, it is the middle of the first decade of April and the beginning of the third decade of April. The mass emergence of the rape blossom beetles takes place when the daily average temperatures are at the range of $9-13^{\circ} \mathrm{C}$ and the sum of the effective temperatures above $5^{\circ} \mathrm{C}$ is at the range of $100-113^{\circ} \mathrm{C}$, it is the middle of the second decade of April and the end of the third decade of April. The females of the rape blossom beetle usually lay 2-3 eggs into one bud of spring rape or mustard.

When protecting the crops from the rape blossom beetle the highest technical efficiency was noted when applying the binary mixture of the microbiological preparation Actophyte, $0.25 \%$ of emulsion concentrate in the dose of $4.8 \mathrm{~L} / \mathrm{ha}$ and systemic insecticide Biscaya, $24 \%$ of oily dispersion ( $0.25 \mathrm{~L} / \mathrm{ha})$ and in 14 days after spraying it was $76.6 \%$ on white mustard, $74.3 \%$ on Chinese mustard and $76.2 \%$ on spring rape. The highest growth increase in the yield capacity was observed in the same variant; for white mustard it was $0.431 \mathrm{t} / \mathrm{ha}$, for Chinese mustard it was $0.265 \mathrm{t} / \mathrm{ha}$ and for spring rape the growth increase amounted to 0.277 t/ha.

As a result of the researches it is established that the weight of 1000 healthy seeds is $2,6996 \mathrm{~g}$, and the weight of the seeds damaged by the larvae of the rape blossom beetle is $0.4213 \mathrm{~g}$, so it is reduced by $84.4 \%$. The filling of the damaged seeds is 6.8 times more, which indicates that they are smaller in diameter and frail. The undamaged seeds of spring rape contain $35.92 \%$ of fat, and the damaged seeds contain only $17.48 \%$, which is 2.05 times less. The protein content in the undamaged seeds was $30.97 \%$ and in the damaged ones it was $32.23 \%$, that is 1.04 times more. The germination rate of the undamaged seeds of spring rape under the laboratory conditions on the eighth day was $90.0 \%$, and the germination rate of the damaged ones amounted to $58.0 \%$ and was lower by $32.0 \%$.
\end{abstract}

Key words: spring rape, mustard, pests, damage, rape blossom beetle, measures of protection.

\section{Introduction}

Rape blossom beetles (Meligethes aeneus) belong to the species Coleoptera or Beetles, a Sap-feeding (Nitidulidae) family, a genus of Meligethes (Yevtushenko et al., 2014; 2016). They can be found everywhere. The beetles are $1.5-2.7 \mathrm{~mm}$ in length and have a flat elongated body, black top with metallic green or blue tint, their antennae are mace like and the legs are black and brown (Fig. 1). The egg is $0.3 \mathrm{~mm}$ in size, it is white, smooth and elongated-oval. The larva is up to $4 \mathrm{~mm}$; it is worm-like, light gray in colour and covered with small black warts, its head is brown (Fig. 2). The pupa is about 3 mm in length, it has a flattenedovate form, and it is of a light yellow colour (Yevtushenko et al., 2014). 


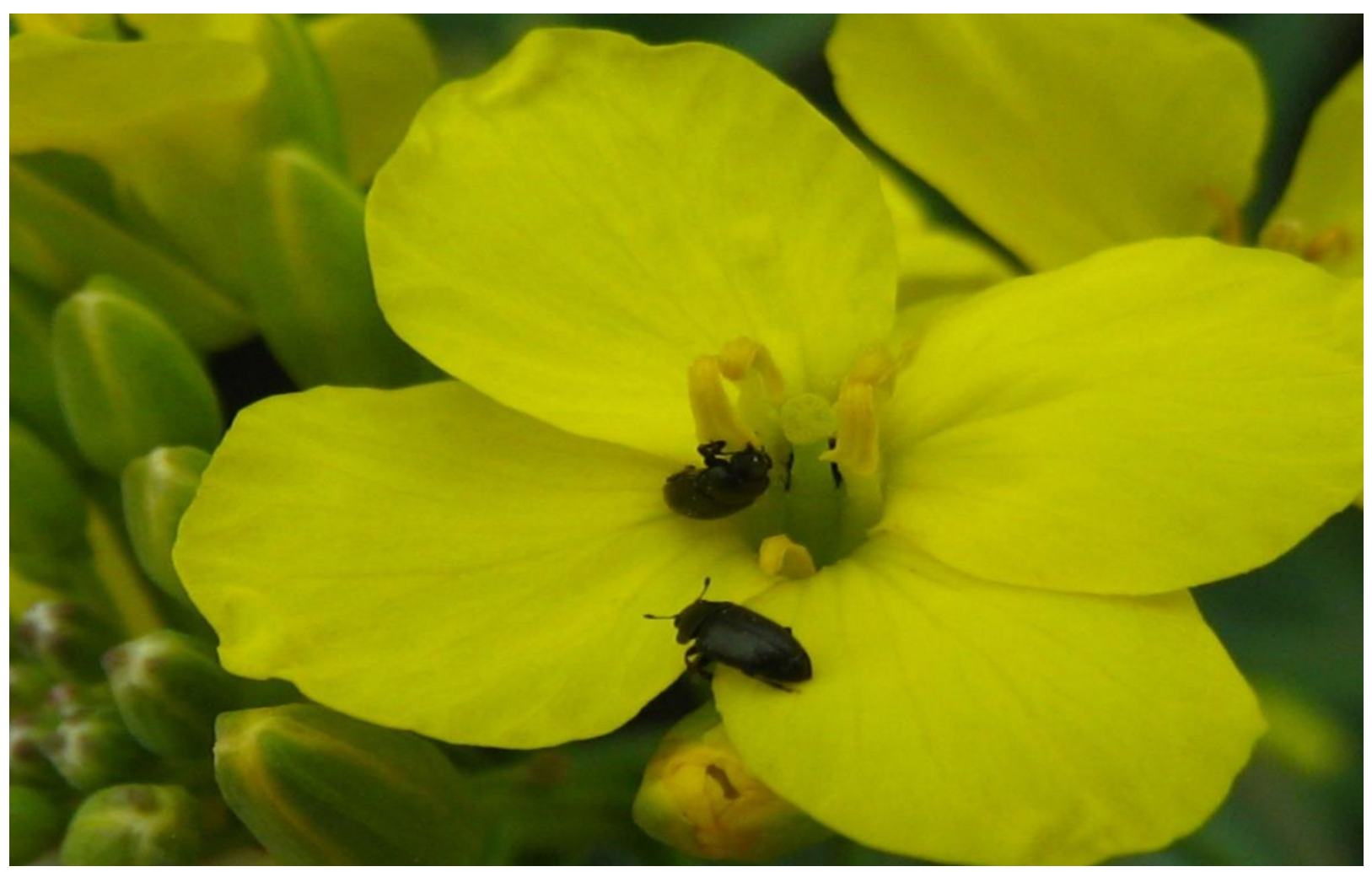

Fig. 1 Imago of rape blossom beetle in a rape flower. Educational, Research and Production Centre "Research Field" of Kharkiv National Agrarian University named after V.V. Dokuchaiev, third decade of June 2018 (photo by the author).

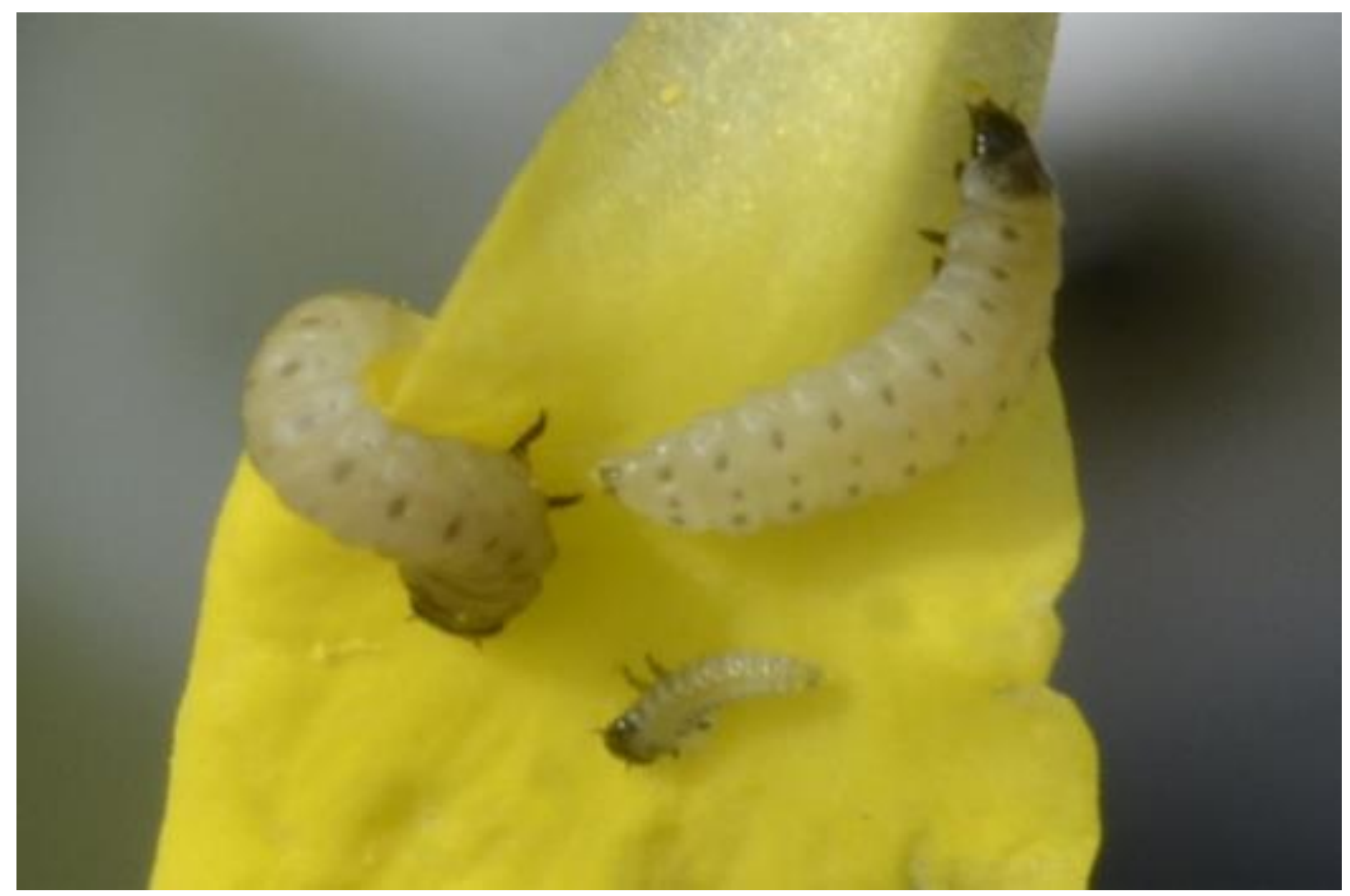

Fig. 2 Larvae of rape blossom beetle of younger and older ages. Educational, Research and Production Centre "Research Field" of Kharkiv National Agrarian University named after V.V. Dokuchaiev, third decade of June 2018 (photo by the author) 
The imagines hibernate on the surface of the soil under the fallen leaves or plant remains on the edges of forests, in gardens and parks. In April and early May the beetles settle on the flowers of wild growing plants (buttercup, dandelion, etc.), then they move to the seeds of cabbage crops (Evtushenko \& Stankevych, 2011; Stankevych, 2012). In addition they feed on the inner parts of buds and flowers, gnawing out the anthers, stamens, pistils and petals. The female lays one or two eggs into the unblown buds and flowers. The fertility is 50-60 eggs. The larvae regenerate after 5-9 days and feed on the inner parts of the buds and flowers, mostly on anthers and sometimes on young pods (Stankevych, 2014). The larval development lasts 15-25 days. After the development the larvae get 2-5 cm deeper into the topsoil and pupate. The pupae develop during 10-12 days. The imagines, which appear in June and July, for some time feed on the flowers of different plants and then fly to the wintering places. In the Eastern Forest-Steppe of Ukraine one generation is developing for a year (Evtushenko \& Stankevych, 2012; Yevtushenko et al., 2014; Stankevych, 2015).

According to the literary data the rape blossom beetle yields one generation a year in the northern regions of Russia, and it yields two or three generations in the central and southern regions (Osmolovskyi, 1972). According to other data the rape blossom beetle yields one-three generations a year in the Volga region (Ivantsova, 2010). In Sweden (Wivstad, 2010) and Norway (Andersen, 2008) the pest yields one generation a year. According to the vast majority of the authors the rape blossom beetle yields two generations in Ukraine (Hurova, 1963; Horodnii, 1970), and according to other data it yields only one generation (Kovalchuk, 1987) or as many as three-four generations (Orobchenko, 1959). According to Academician Fedorenko V.P. (Fedorenko et al., 2008) in Ukraine the rape blossom beetle yields 1 or 2 generations a year, and according to Z.I. Hurova (1963) in the Eastern Forest-Steppe of Ukraine the complete cycle of the first generation of the rape blossom beetle development lasts 36-42 days, and the development of the second generation lasts 26-29 days. In the cold and rainy spring the rape blossom beetle becomes less active and its harmfulness is significantly reduced (Yevtushenko et al., 2014).

The economic threshold of harmfulness of the rape blossom beetle is five-six specimens per plant (Stankevych \& Zabrodina, 2016). The data given by I.V. Kozhanchikov (Kozhanchikov, 1929) and N.L. Sakharov (Sakharov, 1934) are interesting. They emphasise that the presence of the rape blossom beetle does in no way prevent the formation of the high yields of the cabbage crops seeds. It should be noted that the rape blossom beetle is not new to our country and as a pest of rape and other crops from the cabbage family has been mentioned since 1845 (Harmful Insects, 1945). The protective measures include the soil cultivation during the period of the pest mass pupation and spraying the crops at the stage of budding with the insecticides or biological preparations authorised to use if the number of the beetles exceeds the economic threshold of harmfulness (Stankevych, 2012; 2018).

The rape blossom beetle is widespread throughout the territory of Ukraine. It causes the significant damage to the crops every year and reduces the seed yields. The species habitat covers the whole Europe, the Caucasus, Asia Minor and North Africa; as for the countries of Central Asia, the beetle is widespread only in Turkmenistan. The rape blossom beetle is the most dangerous pest of cabbage crops in Germany, Poland and France (Shpaar, 2007).

\section{Material and methods}

To establish the seasonal dynamics of the rape blossom beetle number the calculations were carried out every five days beginning from the budding phase. The beetles were shaken down from the plants into the plastic bags (10 plants in 10 equidistant places of the field). Then the density was converted to an average per 1 plant. On the experimental plots of the Educational, Research and Production Centre "Research Field" of Kharkiv National Agrarian University named after V.V. Dokuchaiev 500 buds were chosen in order to determine the number of the rape blossom beetle eggs in the buds of spring rape and mustard and to clarify the number of the eggs laid into one bud. On each plot from five diagonally located places we chose 20 buds from each of five plants (100 buds from each plot). The buds were placed into the plastic bags and then the buds were opened with a knife and the total number of the eggs of the rape blossom beetle and the number of the eggs in each bud were calculated.

The content of fats and protein in the seeds of spring rape was determined at the laboratory of the Seed Quality of the Plant Growing Institute named after V.Ya. Yuriev of the National Academy of Agrarian Sciences of Ukraine and the seed germination was determined at the laboratory of the Zoology and Entomology Department in Kharkiv National Agrarian University named after V.V. Dokuchaiev.

Influence of the seed treatment agents on the seed germination was evaluated at the laboratory of the Phytopathology Department of Kharkiv National Agrarian University named after V.V. Dokuchaiev and at the laboratory of the Institute of Agrochemistry and Soil Science named after O.N. Sokolovskyi. Germination intensity of the purified seeds harvested in 2012 which had been damaged by the larvae of the rape blossom beetle was determined at the laboratory of the Zoology and Entomology Department in Kharkiv National Agrarian University named after V.V. Dokuchaiev.

Biochemical analysis of the spring rape purified seeds harvested in 2012 as for the fat and protein content was carried out according to the methods of Kjeldahl and Rushkovskyi (Kostromitin, 1975) at the laboratory of the Seed Quality of the Plant Growing Institute named after V.Ya. Yuriev. In order to protect the crops of spring rape and mustard from the rape blossom beetle the experiment as for the influence of the insecticides and their tank mixtures on the quantity and quality of oily cabbage crops yield capacity was laid on the experimental plots of the Educational, Research and Production Centre "Research Field" of Kharkiv National Agrarian University named after V.V. Dokuchaiev.

The plants were sprayed in the phenophase of a yellow bud (before the emergence of the first flowers). The experiments were carried out in 2010-2012 according to the generally accepted method. 
The variants of the experiment are the following:

1. Control $(\mathrm{H} 2 \mathrm{O})$;

2. Actophyte, $0.25 \%$ of emulsion concentrate $\left(2.4 \mathrm{~L} \mathrm{ha}^{-1}\right)$;

3. Actophyte, $0.25 \%$ of emulsion concentrate $\left(4.8 \mathrm{~L} \mathrm{ha}^{-1}\right)$;

4. Biscaya, $24 \%$ of oily dispersion $\left(0.25 \mathrm{~L} \mathrm{ha}^{-1}\right)$;

5. Actophyte, $0.25 \%$ of emulsion concentrate $\left(2.4 \mathrm{~L} \mathrm{ha}^{-1}\right)+$ Biscaya, $24 \%$ of oily dispersion $\left(0.25 \mathrm{~L} \mathrm{ha} \mathrm{h}^{-1}\right)$;

6. Actophyte, $0.25 \%$ of emulsion concentrate $\left(4.8 \mathrm{~L} \mathrm{ha}^{-1}\right)+$ Biscaya, $24 \%$ of oily dispersion $\left(0.25 \mathrm{~L} \mathrm{ha}^{-1}\right)$.

The acreage of the experimental plots under rape and mustard where the insecticides controlling the rape blossom beetle were tested accounted to $5 \mathrm{~m}^{2}$ in triplicate. After 3, 7, and 14 days 25 plants were examined on each plot and the population density of the beetles per 1 plant was determined. Spraying of the crops was carried out with a knapsack sprayer of the "Lemira-SP202-01" brand at a rate of consumption of about $250 \mathrm{~L} \mathrm{ha}^{-1}$. When spraying the crops the technical efficiency of the preparations against the main rape pests was determined by the formula:

$$
T=\frac{a-b}{a} \times 100
$$

where T- technical efficiency, \%;

a - density of the pests population before spraying,

b - density of the pests population in 3, 7 or 14 days after spraying (Recommendations, 1975; Methods of calculation, 1976; Triebel and others, 2001; Stankevich, Zabrodina, 2016).

The economic efficiency or increase in the yield was determined according to the following formula:

$$
I=\frac{a-b}{a} \times 100
$$

where I - increase in the yield, \%;

a - average yield from a calculated unit on a cultivated plot, t;

b - average yield from a calculated unit on a plot under control, t (Recommendations, 1975; Methods, 1976; Triebel et al., Stankevich \& Zabrodina, 2016).

\section{Results}

In the Eastern Forest-Steppe of Ukraine the rape blossom beetle in the imago stage hibernates on the surface of the soil under the fallen leaves or plant remains on the edges of forests, in gardens and parks. In the course of the inspection and calculations conducted in 2007-2012 in the experimental fields of the Educational, Research and Production Centre "Research Field" of Kharkiv National Agrarian University named after V.V. Dokuchaiev and the state enterprise "Research Farm "Elitne" of the Institute of Plant Growing named after V.Ya. Yuryiev of the National Academy of Agrarian Sciences of Ukraine we have found out that the first individuals of the rape blossom beetle appear on the flowering plants (first of all dandelion and buttercup) when the average daily temperature passes through the mark $8^{\circ} \mathrm{C}$. The earliest emergence of the beetles on these plants was observed in 2008, 2010 and 2012. The beetles emerged already in the middle of the first decade of April. In 2007 and 2011 the latest period of the beetles' emergence was observed, it was the beginning of the third decade of April (Table 1).

The mass emergence of the rape blossom beetle took place when the average daily temperatures fluctuated within $9-13^{\circ} \mathrm{C}$ and the sum of the effective temperatures above $5^{\circ} \mathrm{C}$ was $100-113^{\circ} \mathrm{C}$. From the data given in Table 1 it is seen that in 2008 the mass emergence of the rape blossom beetles from the hibernation places was in the middle of the second decade of April and it was the earliest during the research period; and in 2009 the beetles emerged at the end of the third decade of April and it was the latest period oh their emergence.

After the hibernation the rape blossom beetles feed on the pollen of the flowering vegetation, first on dandelion and buttercup, then on the fruit trees (apricot, plum, cherry and apple) and on the weeds from the cabbage family (colza, hedge mustard and field mustard). According to our observations the active populating of spring oily cabbage crops by the rape blossom beetle took place at the very beginning of the budding phenophase (about the second decade of June), although the solitary individuals have been found since the beginning of the rosette formation (in the second decade of May). With the beginning of the budding phase the population density of the rape blossom beetle in the fields under the oily cabbage crops dynamically increases and reaches its peak before flowering. We noted the beginning of the beetles mating in the third decade of May and at the beginning of the first decade of June; and the laying of eggs was noted beginning from the second decade of June.

At the end of the second and at the beginning of the third decade of June the reappearance of the rape blossom beetle larvae was observed; they fed for about 25-30 days and pupated at the end of the third decade of June and at the beginning of the first decade of July. At the end of the first decade of July the emergence of a new generation of the beetles was noted. In the third decade of June, when the plants are in the phase of the pods formation, the beetles begin to leave the field.

The seasonal dynamics of the rape blossom beetle number on spring rape and mustard are shown in the form of diagrams in Figs 3-5. 
Table 1. Terms of beginning and mass emergence of rape blossom beetles on flowering plant. Educational, Research and Production Centre "Research Field" of Kharkiv National Agrarian University named after V.V. Dokuchaiev in 2007-2012

\begin{tabular}{|c|c|c|c|c|c|}
\hline \multirow{2}{*}{ Year } & \multicolumn{2}{|c|}{$\begin{array}{l}\text { Beginning of beetles emergence on } \\
\text { flowering plants }\end{array}$} & \multicolumn{3}{|c|}{ Mass emergence of beetles on flowering plants } \\
\hline & decade & $\begin{array}{l}\text { average daily air } \\
\text { temperature, }{ }^{\circ} \mathrm{C}\end{array}$ & decade & $\begin{array}{l}\text { average daily air } \\
\text { temperature, }{ }^{\circ} \mathrm{C}\end{array}$ & $\begin{array}{l}\text { sum of effective } \\
\text { temperatures, }{ }^{\circ} \mathrm{C}\end{array}$ \\
\hline 2007 & $\begin{array}{l}\text { beginning of } \\
\text { the third } \\
\text { decade of } \\
\text { April }\end{array}$ & 9.1 & $\begin{array}{l}\text { middle of the } \\
\text { third decade } \\
\text { of April }\end{array}$ & 9.1 & 103.9 \\
\hline 2008 & $\begin{array}{c}\text { middle of the } \\
\text { first decade of } \\
\text { April }\end{array}$ & 11.0 & $\begin{array}{l}\text { middle of the } \\
\text { second } \\
\text { decade of } \\
\text { April }\end{array}$ & 11.5 & 112.9 \\
\hline 2009 & $\begin{array}{l}\text { end of the } \\
\text { second } \\
\text { decade of } \\
\text { April }\end{array}$ & 8.6 & $\begin{array}{l}\text { end of the } \\
\text { third decade } \\
\text { of April }\end{array}$ & 11.5 & 101.0 \\
\hline 2010 & $\begin{array}{c}\text { middle of the } \\
\text { first decade of } \\
\text { April }\end{array}$ & 9.1 & $\begin{array}{l}\text { end of the } \\
\text { second } \\
\text { decade of } \\
\text { April }\end{array}$ & 10.9 & 110.0 \\
\hline 2011 & $\begin{array}{l}\text { beginning of } \\
\text { the third } \\
\text { decade of } \\
\text { April }\end{array}$ & 11.7 & $\begin{array}{l}\text { middle of the } \\
\text { third decade } \\
\text { of April }\end{array}$ & 10.6 & 105.9 \\
\hline 2012 & $\begin{array}{c}\text { middle of the } \\
\text { first decade of } \\
\text { April }\end{array}$ & 9,7 & $\begin{array}{l}\text { middle of the } \\
\text { second } \\
\text { decade of } \\
\text { April }\end{array}$ & 13.5 & 103.5 \\
\hline
\end{tabular}

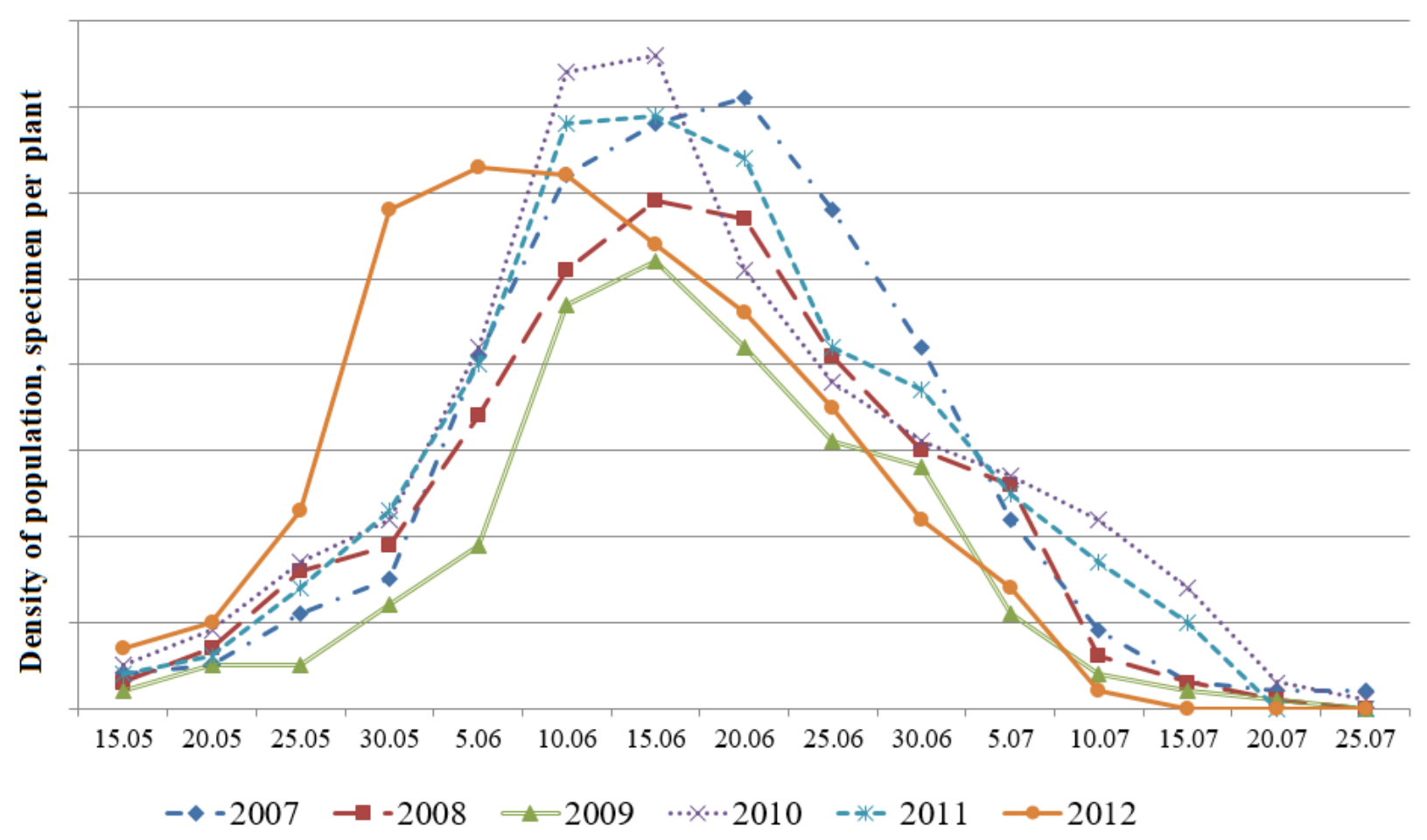

Fig. 3 Seasonal dynamics of rape blossom beetle number on spring rape crops in Eastern Forest-Steppe of Ukraine in 20072012 
Analysing the data from Figs 3-5 it can be seen that at Educational, Research and Production Centre "Research Field" of Kharkiv National Agrarian University named after V.V. Dokuchaiev the first individuals of the rape blossom beetle begin to populate the crops of spring oily cabbage crops in the middle of the second decade of May. During the years of the researches the peak of the rape blossom beetle number on the oily cabbage crops was noted from the end of the third decade of May to the end of the second decade of June when the plants are in the phenophases of budding and flowering. Beginning from the third decade of June during the phenophase of the pods growth the beetles begin to leave the field; only some larvae, which have not finished feeding on the buds and flowers and are still feeding on the young pods and seeds, remain on the plants.

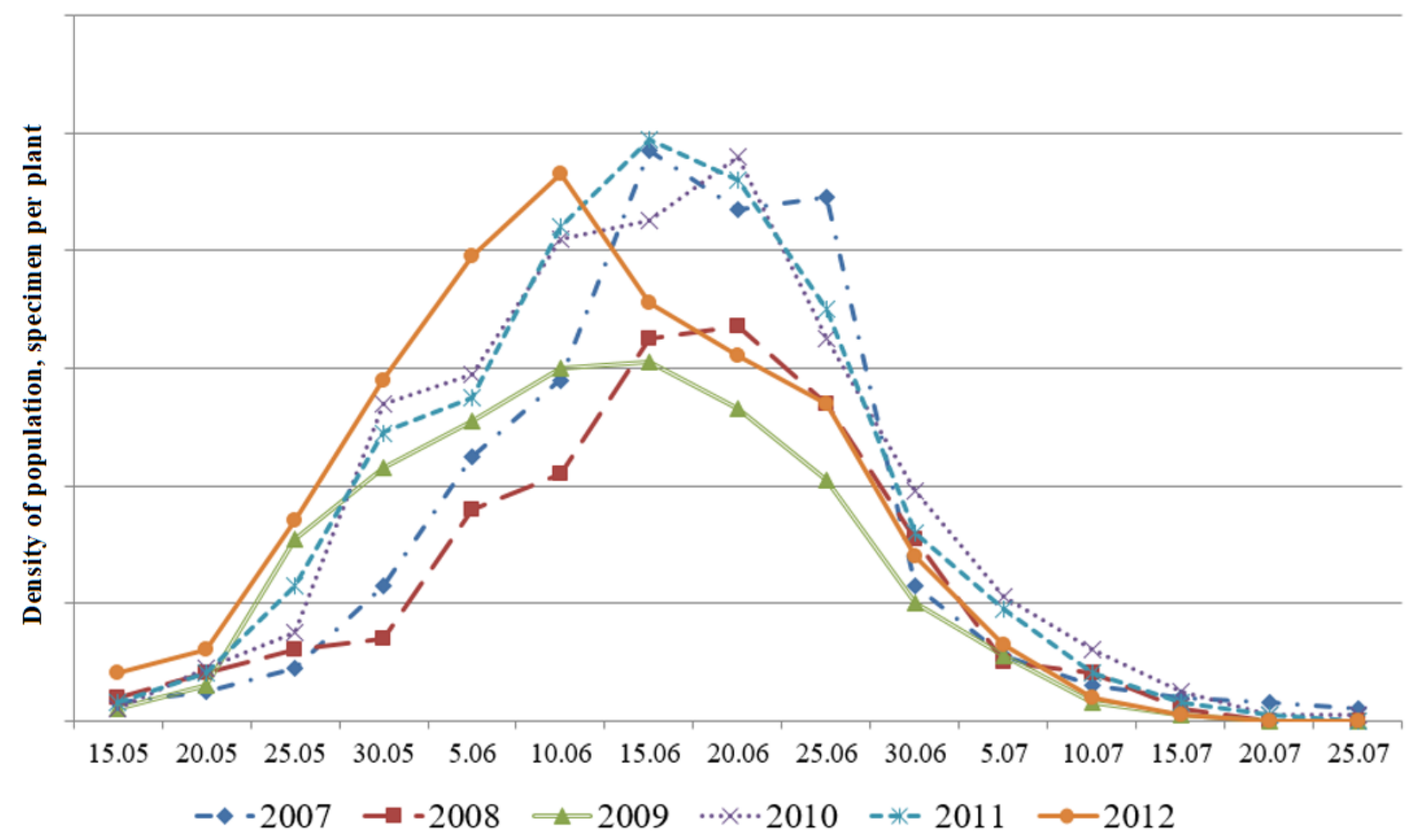

Fig. 4. Seasonal dynamics of rape blossom beetle number on white mustard crops in Eastern Forest-Steppe of Ukraine in 20072012

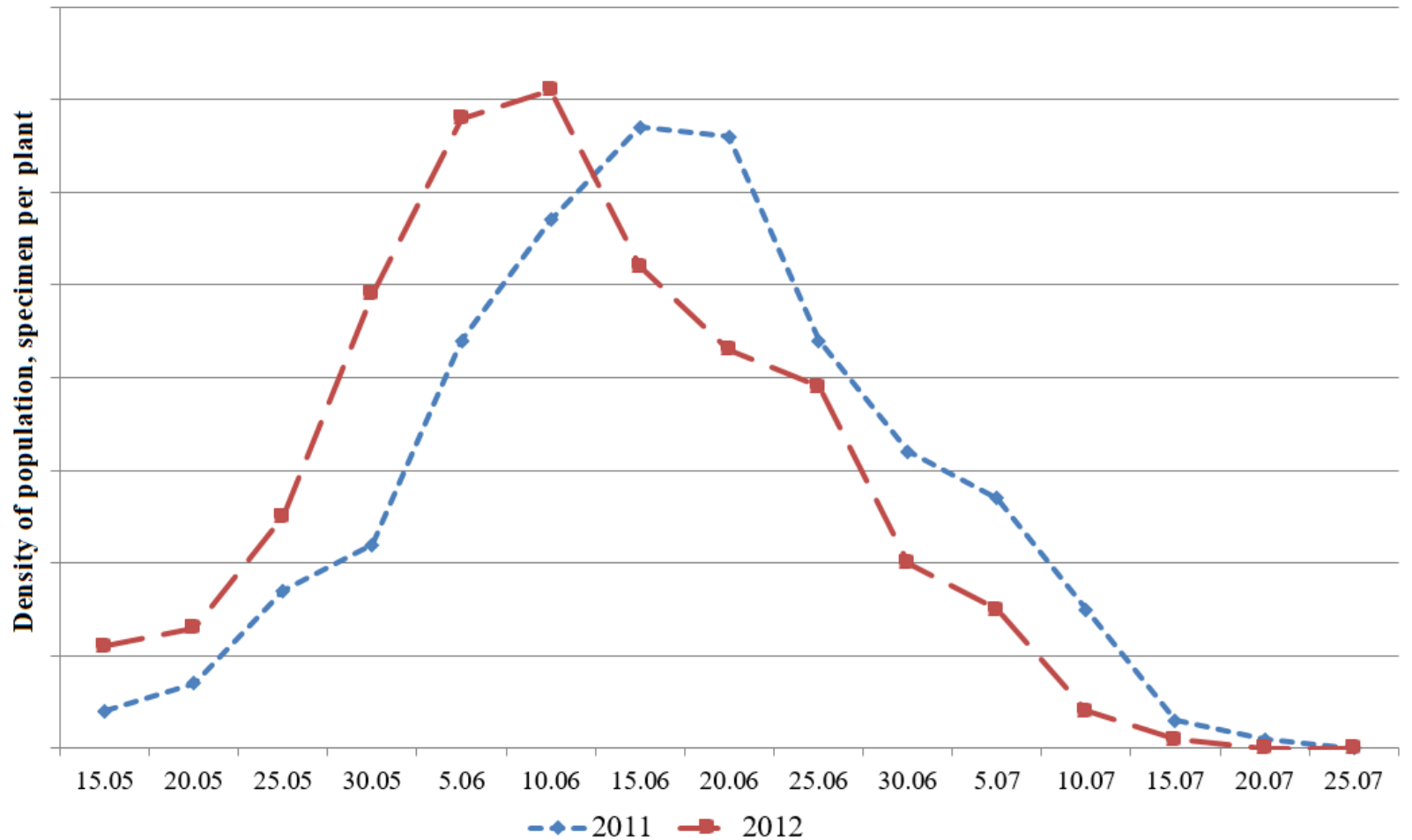

Fig. 5 Seasonal dynamics of rape blossom beetle number on Chinese mustard crops in Eastern Forest-Steppe of Ukraine in 2011-2012 
In order to determine the number of the spring rape buds populated by the eggs of the rape blossom beetle and to clarify the number of the eggs laid into one bud on the experimental plots of the Educational, Research and Production Centre "Research Field" of Kharkiv National Agrarian University named after V.V. Dokuchaiev we chose 500 buds.

On each plot from 5 diagonally located places we chose 20 buds from each of 5 plants (100 buds from each place). The buds were placed into the plastic bags and then the buds were opened with a knife and the total number of the eggs of the rape blossom beetle and the number of the eggs in each bud were calculated. The obtained data are shown in Table 2.

Table 2. Number of rape blossom beetle eggs in the buds of spring rape and mustard.

\begin{tabular}{|c|c|c|c|c|c|c|c|c|c|}
\hline \multirow{3}{*}{ Crops } & \multirow{3}{*}{$\begin{array}{l}\text { Years of } \\
\text { researches }\end{array}$} & \multicolumn{8}{|c|}{ Number of eggs in the buds } \\
\hline & & 0 & & 2 & 3 & 1 & & & \\
\hline & & 0 & 1 & 2 & 3 & 4 & 5 & populated & unpopulated \\
\hline \multirow{3}{*}{ Spring rape } & 2010 & 303 & 29 & 53 & 75 & 23 & 17 & 39.4 & 60.2 \\
\hline & 2011 & 321 & 32 & 41 & 89 & 12 & 5 & 35.8 & 64.2 \\
\hline & 2012 & 319 & 29 & 47 & 82 & 14 & 9 & 36.8 & 63.8 \\
\hline \multirow{3}{*}{$\begin{array}{l}\text { White } \\
\text { mustard }\end{array}$} & 2010 & 314 & 26 & 49 & 67 & 29 & 15 & 37.2 & 62.8 \\
\hline & 2011 & 330 & 35 & 48 & 60 & 15 & 12 & 34.0 & 66.0 \\
\hline & 2012 & 327 & 29 & 44 & 73 & 19 & 8 & 34.6 & 65.4 \\
\hline \multirow{2}{*}{$\begin{array}{l}\text { Chinese } \\
\text { mustard }\end{array}$} & 2011 & 307 & 38 & 56 & 68 & 22 & 9 & 38.6 & 61.4 \\
\hline & 2012 & 315 & 23 & 49 & 87 & 15 & 11 & 37.0 & 63.0 \\
\hline
\end{tabular}

Here and later at Educational, Research and Production Centre "Research Field" of Kharkiv National Agrarian University named after V.V. Dokuchaiev in 2010-2012

From the data given in Table 2 it is seen that the total populating of spring rape buds with the eggs of the rape blossom beetle was $39.4 \%$ in 2010, in 2011 it was $35.8 \%$ and in 2012 it was $36.2 \%$. The populating of white mustard buds with the eggs of the rape blossom beetle was 37.2\% in 2010, in 2011 it was $34.0 \%$, and in 2012 it was $34.6 \%$. The populating of Chinese mustard buds with the eggs of the rape blossom beetle amounted to $38.6 \%$ in 2011, and in 2012 it was 37,0 \%. We noted from 1 to 5 eggs laid into the populated buds, but most often there were 2-3 eggs (Table 2). Six or more eggs in one bud were not found. Usually the mass populating of the plants with the rape blossom beetles takes place during the period of oily cabbage crops budding. At this time it is important to use the protective measures in the shortest possible time, namely it is necessary to spray the plants before flowering (in the phenophase of a yellow bud) since spraying during the flowering will cause harm to the beneficial entomofauna and insect pollinators. This is extremely important because the insects pollinate $85 \%$ of flower plants (95\% of which are the bees).

Taking into account the fact that most insecticides have a negative influence on the number of the entomophages and pollinators which in their mass populate the crops of white mustard during the phase of flowering and in order to expand the range of the insecticides that are effective in protecting oily cabbage crops from the rape blossom beetle we have examined the influence of a new microbiological preparation Actophyte, $0.25 \%$ of emulsion concentrate on the rape blossom beetle by spraying the plants before flowering.

The biological preparations are not harmful to birds, warm-blooded animals, beneficial entomofauna and humans. The microbiological preparation Actophyte, $0.25 \%$ of emulsion concentrate (active substance aversectin) has been applied by us at different rates of consumption and in a combination with the insecticide of systemic action Biscaya, $24 \%$ of oily dispersion (active substance thiacloprid) on the crops of spring rape of Ataman variety, white mustard of Carolina variety and Chinese mustard of Tavrychanka variety.

Actophyte, $0.25 \%$ of emulsion concentrate is a microbiological preparation which has an insectoacaricide action. The dry and clear weather is a necessary condition for its application. The active substance of the preparation is a complex of natural avermectins which are produced by the non-pathogenic soil radiant fungus (Streptomyces avermitilis).

Biscaya, $24 \%$ of oily dispersion is a systemic insecticide which due to its preparative forms (oily dispersion) is very well kept on the leaves of the cabbage crops abundantly covered with a bloom and does not require the additional use of the adhesions. The preparation is not toxic to the bees and bumble-bees.

As a result of spraying the crops in the phase of the yellow bud we have found that spraying of spring rape and mustard is a reliable way to protect them from the rape blossom beetle.

In the course of the researches the following data (Tables 3-5 and Fig. 6) regarding the technical efficiency of the preparations action were obtained. As it can be seen from the data given in Tables 3-5 the preparations have a toxic effect on the rape blossom beetle. However the binary mixture of the microbiological preparation Actophyte, $0.25 \%$ of emulsion concentrate (4.8 L ha-1) and the systemic insecticide Biscaya, $24 \%$ of oily dispersion $(0.25 \mathrm{~L} / \mathrm{ha})$ turned to be the best one.

The technical efficiency of the given mixture in 14 days after spraying constituted $76.6 \%$ on white mustard, on Chinese mustard it was $73.4 \%$ and on spring rape it was $76.2 \%$. The binary mixture of the microbiological preparation Actophyte, $0.25 \%$ of emulsion concentrate (2.4 L/ha) and the systemic insecticide Biscaya, $24 \%$ of oily dispersion $\left(0.25 \mathrm{~L}^{-1}\right)$ was less effective.

The technical efficiency of the mixture Actophyte, $0.25 \%$ of emulsion concentrate $\left(2.4 \mathrm{~L} \mathrm{ha}^{-1}\right)+$ Biscaya, $24 \%$ of oily dispersion $\left(0.25 \mathrm{~L} \mathrm{ha}^{-1}\right)$ in 14 days after spraying was $71.3 \%$ on white mustard, $71.2 \%$ on Chinese mustard, and $69.7 \%$ on spring rape. The systemic insecticide Biscaya, $24 \%$ of oily dispersion at the consumption rate of $0.25 \mathrm{~L} \mathrm{ha}^{-1}$ in 14 days after spraying showed the technical efficiency at the level of $67.9 \%$ on white mustard, $67.3 \%$ on Chinese mustard and $68.2 \%$ on spring rape. The least effective were the variants when using the microbiological preparation Actophyte, $0.25 \%$ of emulsion concentrate at the 
consumption rate of 2.4 and $4.8 \mathrm{~L} \mathrm{ha}^{-1}$. The technical efficiency when applying Actophyte, $0.25 \%$ of emulsion concentrate at the rate of $2.4 \mathrm{~L} \mathrm{ha}^{-1}$ in 14 days after spraying was $22.1 \%$ on white mustard, $24.4 \%$ on Chinese mustard and $18.7 \%$ on spring rape; and at the rate of $4,8 \mathrm{~L} / \mathrm{ha}$ the technical efficiency on white mustard was $28,3 \%$, on Chinese mustard it was $28.8 \%$ and on spring rape it was $26.1 \%$.

Table 3. Technical efficiency of preparations Actophyte, $0.25 \%$ of emulsion concentrate and Biscaya, $24 \%$ of oily dispersion when protecting white mustard of Carolina variety from rape blossom beetle in phenophase of a yellow bud.

Variants of research

\begin{tabular}{|c|c|c|c|c|c|c|}
\hline Period & $\begin{array}{l}\text { Control } \\
(\mathrm{H} 2 \mathrm{O})\end{array}$ & $\begin{array}{c}\text { Actophyte, } 0.25 \% \\
\text { of emulsion } \\
\text { concentrate } \\
\left(2.4 \mathrm{~L} \mathrm{ha}^{-1}\right)\end{array}$ & $\begin{array}{c}\text { Actophyte, } 0.25 \% \\
\text { of emulsion } \\
\text { concentrate } \\
\left(4.8 \text { L ha }^{-1}\right)\end{array}$ & $\begin{array}{c}\text { Biscaya, } 24 \% \text { of } \\
\text { oily dispersion } \\
\left(0.25 \text { L ha }^{-1}\right)\end{array}$ & $\begin{array}{c}\text { Actophyte, } 0.25 \% \text { of } \\
\text { emulsion concentrate } \\
\left(2.4 \mathrm{~L} \mathrm{ha}^{-1}\right)+\text { Biscaya, } \\
24 \% \text { of oily dispersion } \\
\left(0.25 \mathrm{~L} \mathrm{ha}^{-1}\right)\end{array}$ & $\begin{array}{l}\text { of emulsion } \\
\text { concentrate } \\
\left(4.8 \mathrm{~L} \mathrm{ha}^{-1}\right)+ \\
\text { Biscaya, } 24 \% \text { of } \\
\text { oily dispersion } \\
\left(0.25 \mathrm{~L} \mathrm{ha}^{-1}\right)\end{array}$ \\
\hline
\end{tabular}

Technical efficiency (\%) in 3, 7 and 14 days after spraying

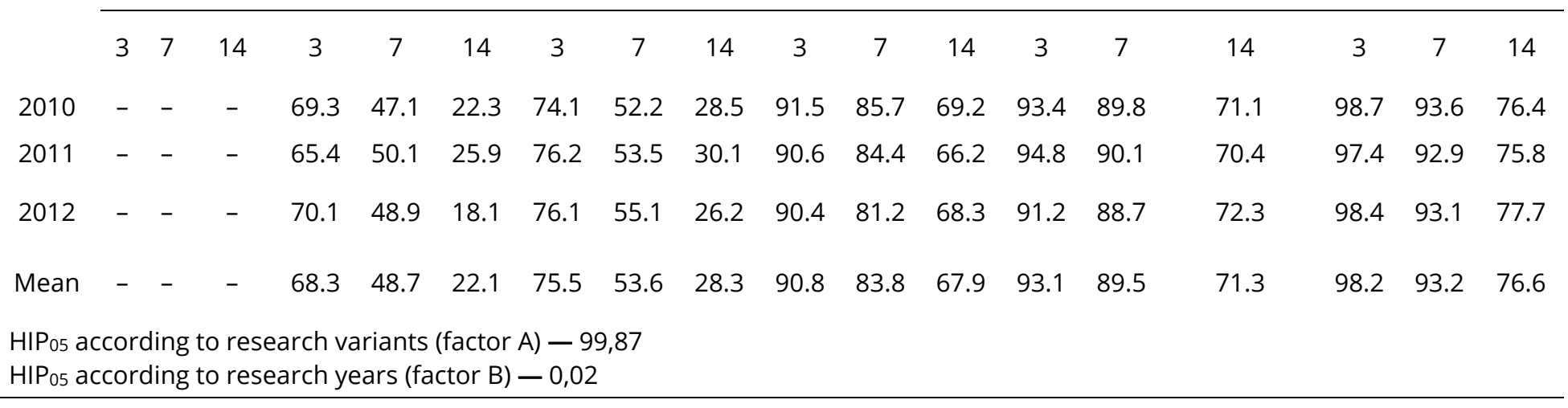

Table 4. Technical efficiency of preparations Actophyte, $0.25 \%$ of emulsion concentrate and Biscaya, $24 \%$ of oily dispersion when protecting Chinese mustard of Tavrychanka variety from rape blossom beetle in phenophase of a yellow bud

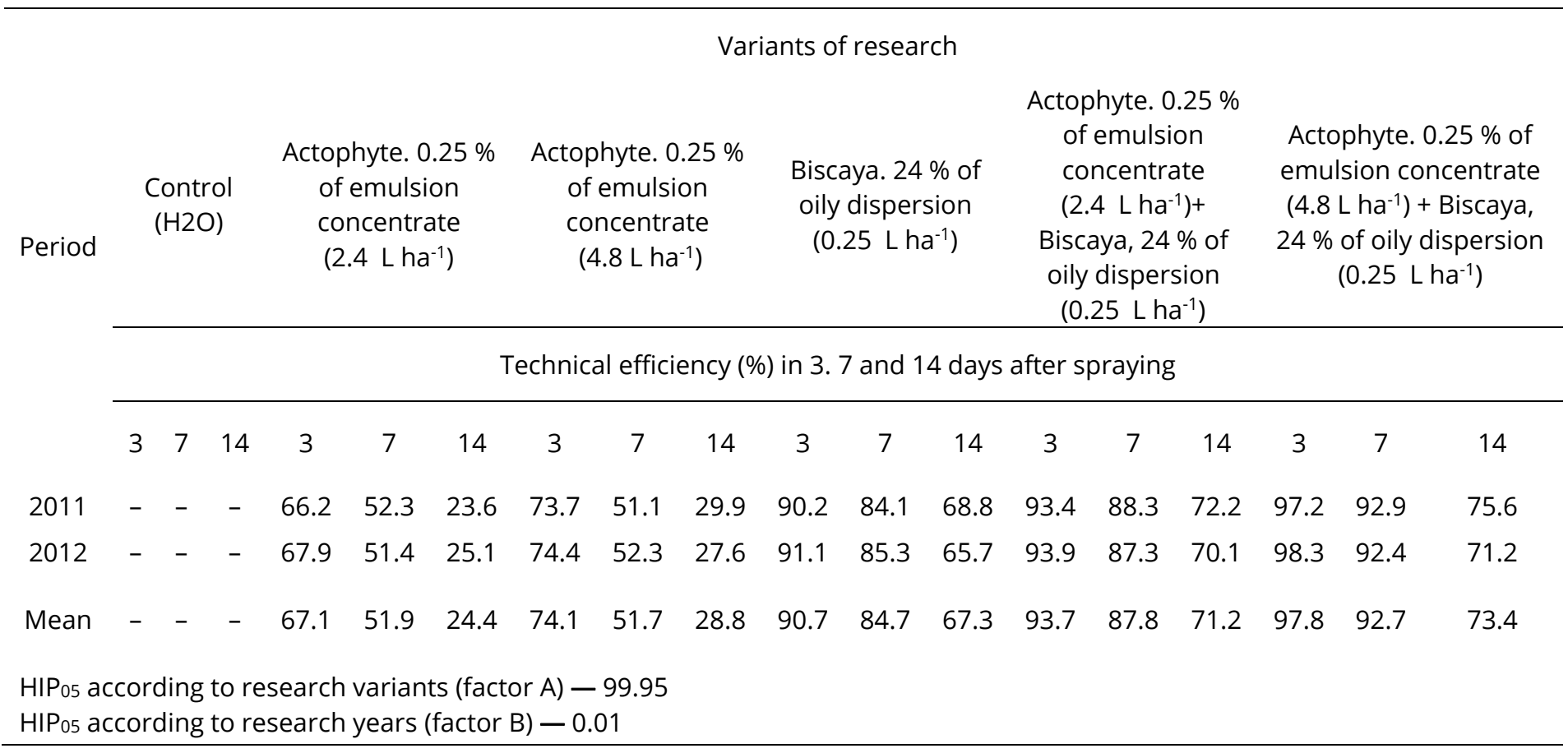


Table 5. Technical efficiency of preparations Actophyte, 0,25 \% of emulsion concentrate and Biscaya, $24 \%$ of oily dispersion when protecting spring rape of Ataman variety from rape blossom beetle in phenophase of a yellow bud

Variants of research

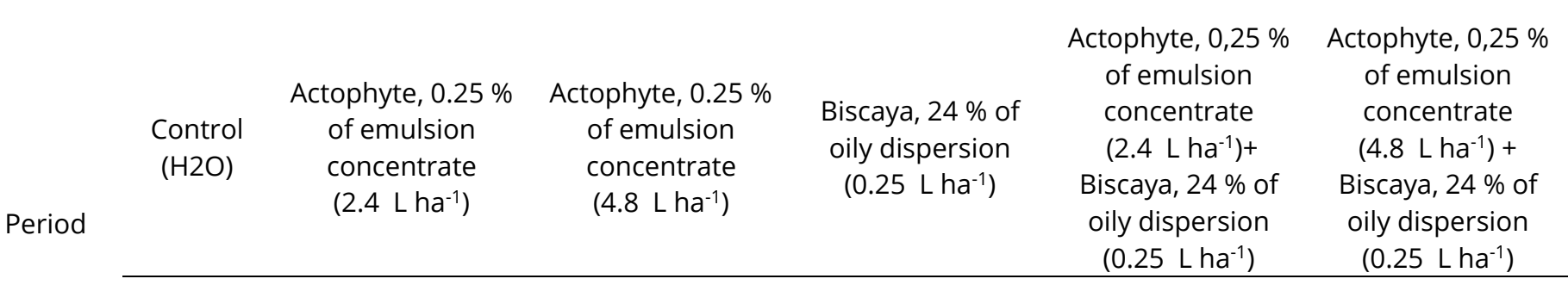

Technical efficiency (\%) in 3, 7 and 14 days after spraying

$\begin{array}{rrrrrrrrrrrrrrrrrrrrr} & 3 & 7 & 14 & 3 & 7 & 14 & 3 & 7 & 14 & 3 & 7 & 14 & 3 & 7 & 14 & 3 & 7 & 14 \\ 2011 & - & - & - & 68.8 & 50.3 & 19.1 & 75.3 & 49.7 & 25.4 & 90.3 & 83.2 & 69.9 & 94.7 & 87.9 & 70.7 & 98.3 & 93.4 & 76.9 \\ 2012 & - & - & - & 69.3 & 52.8 & 18.2 & 76.2 & 53.1 & 26.7 & 91.4 & 84.9 & 66.4 & 93.1 & 88.2 & 68.6 & 96.9 & 91.3 & 75.4 \\ \text { Average } & - & - & - & 69.1 & 51.6 & 18.7 & 75.8 & 51.4 & 26.1 & 90.9 & 84.1 & 68.2 & 93.9 & 88.1 & 69.7 & 97.6 & 92.4 & 76.2\end{array}$

HIP05 according to research variants (factor $\mathrm{A})-99,95$

HIP05 according to research years (factor $\mathrm{B})-0,01$

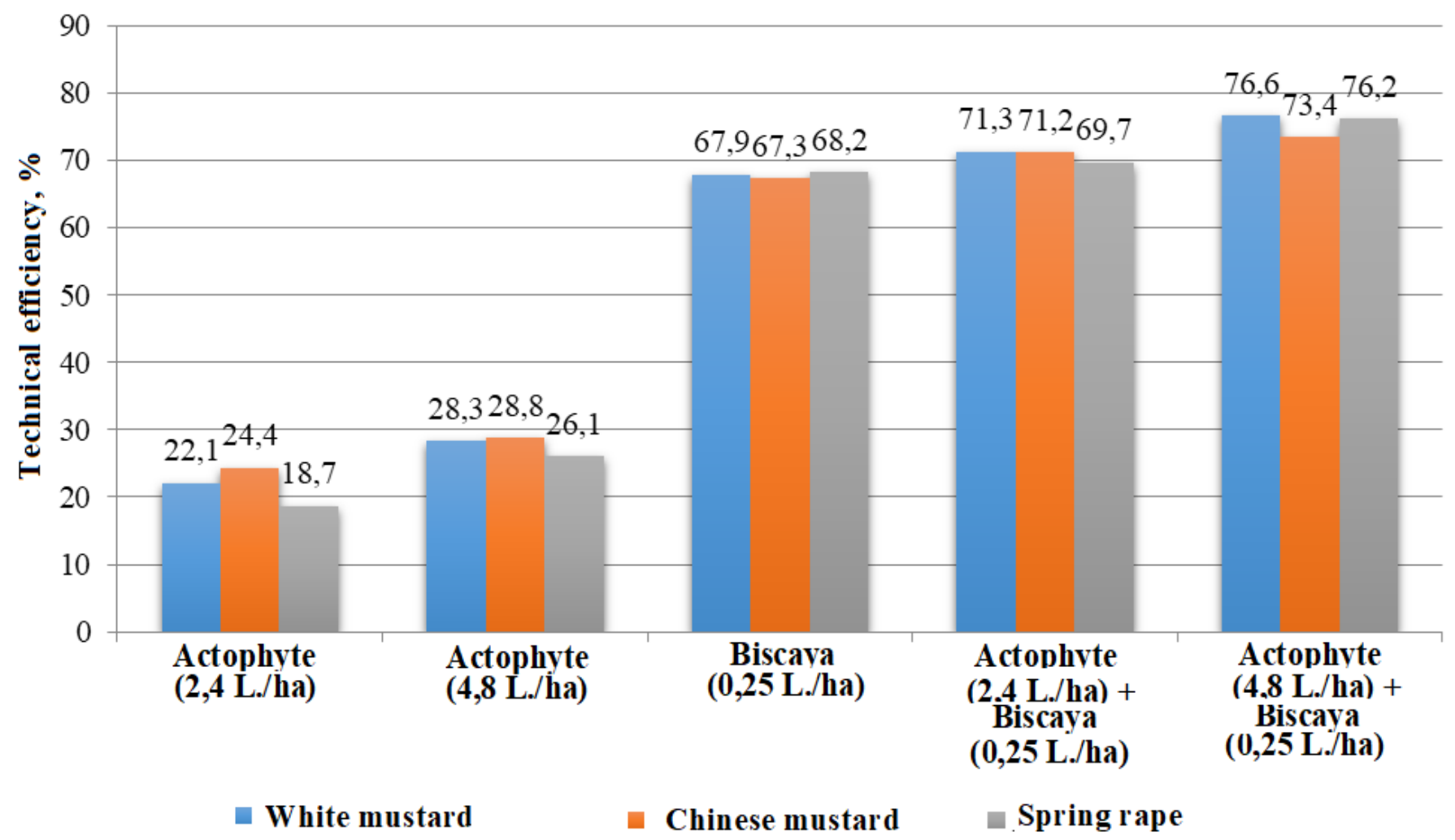

Fig. 6 Technical efficiency of preparations Actophyte, $0.25 \%$ of emulsion concentrate and Biscaya, $24 \%$ of oily dispersion in 14 days after spraying spring rape and mustard against rape blossom beetle in phenophase of a yellow bud 
Table 6. Economic efficiency of preparations Actophyte, $0.25 \%$ of emulsion concentrate and Biscaya, $24 \%$ of oily dispersion when protecting white mustard of Carolina variety from rape blossom beetle in phenophase of a yellow bud.

Variants of research

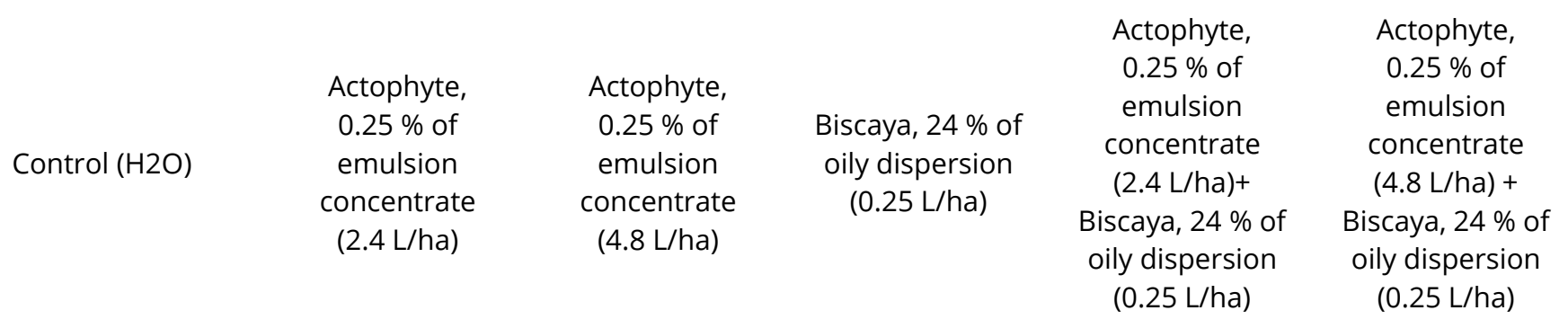

\begin{tabular}{|c|c|c|c|c|c|c|c|c|c|c|c|}
\hline $\begin{array}{c}\text { Yield } \\
\text { capacity, } \\
\text { t/ha }\end{array}$ & $\begin{array}{c}\text { Yield } \\
\text { saved,t/ha }\end{array}$ & $\begin{array}{c}\text { Yield } \\
\text { capacity, } \\
\text { t/ha }\end{array}$ & $\begin{array}{c}\text { Yield } \\
\text { saved, } \\
\text { t/ha }\end{array}$ & $\begin{array}{c}\text { Yield } \\
\text { capacity } \\
\text { t/ha }\end{array}$ & $\begin{array}{c}\text { Yield } \\
\text { saved, } \\
\text { t/ha }\end{array}$ & $\begin{array}{c}\text { Yield } \\
\text { capacity, } \\
\text { t/ha }\end{array}$ & $\begin{array}{c}\text { Yield } \\
\text { saved, } \\
\text { t/ha }\end{array}$ & $\begin{array}{c}\text { Yield } \\
\text { capacity, } \\
\text { t/ha }\end{array}$ & $\begin{array}{c}\text { Yield } \\
\text { saved, } \\
\text { t/ha }\end{array}$ & $\begin{array}{c}\text { Yield } \\
\text { capacity, } \\
\text { t/ha }\end{array}$ & $\begin{array}{c}\text { Yield } \\
\text { saved, } \\
\text { t/ha }\end{array}$ \\
\hline
\end{tabular}

$\begin{array}{cccccccccccccccc}2010 & 0.521 & - & 0.734 & 0.213 & 0.759 & 0.248 & 1.078 & 0.557 & 1.161 & 0.64 & 1.213 & 0.692 \\ 2011 & 0.273 & - & 0.406 & 0.133 & 0.454 & 0.181 & 0.532 & 0.259 & 0.621 & 0.348 & 0.672 & 0.399 \\ 2012 & 0.103 & - & 0.146 & 0.043 & 0.169 & 0.066 & 0.21 & 0.107 & 0.282 & 0.179 & 0.305 & 0.202 \\ \text { Average } & 0.299 & - & 0.429 & 0.13 & 0.461 & 0.162 & 0.607 & 0.308 & 0.688 & 0.389 & 0.73 & 0.431\end{array}$

HIP05 according to research variants (factor $\mathrm{A})-0,19$

HIP05 according to research years (factor $B)-0,13$

Table 7. Economic efficiency of preparations Actophyte, 0,25\% of emulsion concentrate and Biscaya, $24 \%$ of oily dispersion when protecting Chinese mustard of Tavrychanka variety from rape blossom beetle in phenophase of a yellow bud.

\begin{tabular}{|c|c|c|c|c|c|c|c|c|c|c|c|c|}
\hline \multirow{3}{*}{ Period } & \multicolumn{12}{|c|}{ Variants of research } \\
\hline & \multicolumn{2}{|c|}{ Control $\left(\mathrm{H}_{2} \mathrm{O}\right)$} & \multicolumn{2}{|c|}{$\begin{array}{c}\text { Actophyte, } 0, .5 \% \\
\text { of emulsion } \\
\text { concentrate } \\
\text { (2.4 L/ha) }\end{array}$} & \multicolumn{2}{|c|}{$\begin{array}{l}\text { Actophyte, } \\
0.25 \% \text { of } \\
\text { emulsion } \\
\text { concentrate } \\
(4.8 \text { L/ha })\end{array}$} & \multicolumn{2}{|c|}{$\begin{array}{c}\text { Biscaya, } 24 \% \text { of } \\
\text { oily dispersion } \\
(0.25 \mathrm{~L} / \mathrm{ha})\end{array}$} & \multicolumn{2}{|c|}{$\begin{array}{c}\text { Actophyte, } \\
0.25 \% \text { of } \\
\text { emulsion } \\
\text { concentrate } \\
(2.4 \mathrm{~L} / \mathrm{ha})+ \\
\text { Biscaya, } 24 \% \text { of } \\
\text { oily dispersion } \\
\text { (0.25 L/ha) }\end{array}$} & \multicolumn{2}{|c|}{$\begin{array}{c}\text { Actophyte, } \\
0.25 \% \text { of } \\
\text { emulsion } \\
\text { concentrate } \\
(4.8 \mathrm{~L} / \mathrm{ha})+ \\
\text { Biscaya, } 24 \% \text { of } \\
\text { oily dispersion } \\
\text { (0.25 L/ha) }\end{array}$} \\
\hline & $\begin{array}{l}\text { Yield } \\
\text { capacity, } \\
\text { t/ha }\end{array}$ & $\begin{array}{l}\text { Yield } \\
\text { saved, } \\
\text { t/ha }\end{array}$ & $\begin{array}{l}\text { Yield } \\
\text { capacity, } \\
\text { t/ha }\end{array}$ & $\begin{array}{l}\text { Yield } \\
\text { saved. } \\
\text { t/ha }\end{array}$ & $\begin{array}{l}\text { Yield } \\
\text { capacity } \\
\text { t/ha }\end{array}$ & $\begin{array}{l}\text { Yield } \\
\text { saved, } \\
\text { t/ha }\end{array}$ & $\begin{array}{l}\text { Yield } \\
\text { capacity, } \\
\text { t/ha }\end{array}$ & $\begin{array}{l}\text { Yield } \\
\text { saved, } \\
\text { t/ha }\end{array}$ & $\begin{array}{l}\text { Yield } \\
\text { capacity, } \\
\text { t/ha }\end{array}$ & $\begin{array}{l}\text { Yield } \\
\text { saved, } \\
\text { t/ha }\end{array}$ & $\begin{array}{l}\text { Yield } \\
\text { capacity, } \\
\text { t/ha }\end{array}$ & $\begin{array}{c}\text { Yield } \\
\text { saved, } \\
\text { t/ha }\end{array}$ \\
\hline 2011 & 0.302 & - & 0.465 & 0.163 & 0.471 & 0.169 & 0.492 & 0.19 & 0.569 & 0.267 & 0.655 & 0.353 \\
\hline 2012 & 0.096 & - & 0.135 & 0.39 & 0.148 & 0.052 & 0.214 & 0.118 & 0.237 & 0.141 & 0.273 & 0.177 \\
\hline Average & 0.199 & - & 0.3 & 0.101 & 0.31 & 0.111 & 0.353 & 0.154 & 0.403 & 0.204 & 0.464 & 0.265 \\
\hline
\end{tabular}

After harvesting, cleaning and analysing the crops of spring rape and mustard we obtained the following data (Tables 6-8,

Fig. 7) as for the economic efficiency of the used preparations and their mixtures.

As it is seen from the data given in Tables 6-8 in all variants of the experiment the increase in the yield capacity was noted, however the binary mixture of the microbiological preparation Actophyte, $0.25 \%$ of emulsion concentrate (4.8 L//ha) and systemic insecticide Biscaya, $24 \%$ of oily dispersion ( $0.25 \mathrm{~L} / \mathrm{ha})$ was the best one. The increase in the yield capacity of white mustard accounted to $0.431 \mathrm{t} / \mathrm{ha}$, the growth increase in Chinese mustard was $0.265 \mathrm{t} / \mathrm{ha}$ and spring rape gave the increase of 
$0.277 \mathrm{t} / \mathrm{ha}$. The increase in the yield capacity when applying the binary mixture of the microbiological preparation Actophyte, $0.25 \%$ of emulsion concentrate (2.4 L/ha) and systemic insecticide Biscaya, $24 \%$ of oily dispersion (0,25 L/ha) was slightly lower. The increase in the yield capacity of white mustard was $0.389 \mathrm{t} / \mathrm{ha}$, the increase in Chinese mustard was $0.204 \mathrm{t} / \mathrm{ha}$, and spring rape gave the increase of $0.234 \mathrm{t} / \mathrm{ha}$. The application of the systemic insecticide Biscaya, $24 \%$ of oily dispersion at the rate of consumption of $0.25 \mathrm{~L} / \mathrm{ha}$ provided the saved yield of white mustard at the level of $0.308 \mathrm{t} / \mathrm{ha}$, the yield of Chinese mustard was saved at the level of $0.154 \mathrm{t} / \mathrm{ha}$, and the yield of spring rape was saved at the level of $0.174 \mathrm{t} / \mathrm{ha}$.

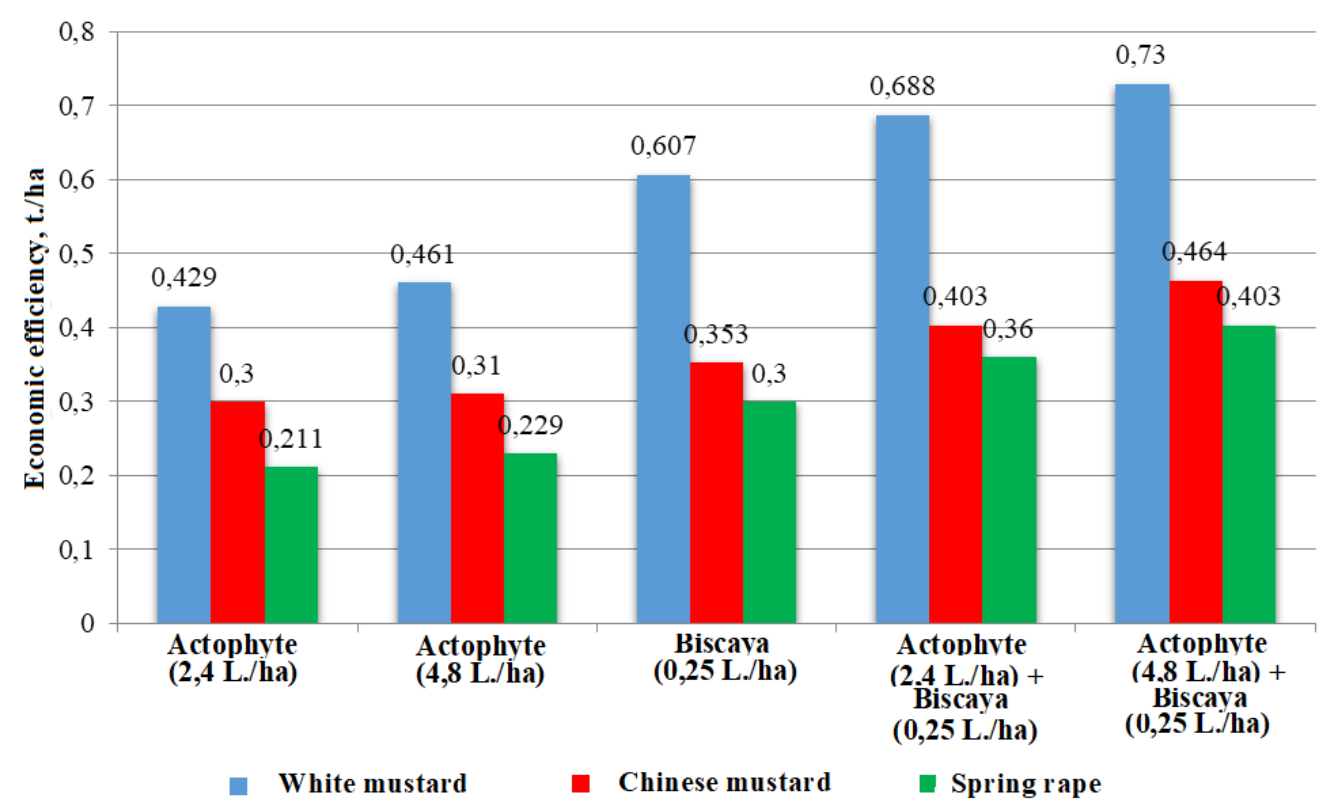

Fig. 7 Economic efficiency of preparations Actophyte, $0.25 \%$ of emulsion concentrate and Biscaya, $24 \%$ of oily dispersion when protecting mustard and spring rape from rape blossom beetle in phenophase of a yellow bud

Table 8. Economic efficiency of preparations Actophyte, 0,25\% of emulsion concentrate and Biscaya, $24 \%$ of oily dispersion when protecting spring rape of Ataman variety from rape blossom beetle in phenophase of a yellow bud at Educational, Research and Production Centre "Research Field" of Kharkiv National Agrarian University named after V.V. Dokuchaiev in 2011-2012

Variants of research

\begin{tabular}{|c|c|c|c|c|c|}
\hline Control $(\mathrm{H} 2 \mathrm{O})$ & $\begin{array}{c}\text { Actophyte, } \\
0.25 \% \text { of } \\
\text { emulsion } \\
\text { concentrate } \\
(2.4 \text { L/ha) }\end{array}$ & $\begin{array}{c}\text { Actophyte, } 0.25 \% \\
\text { of emulsion } \\
\text { concentrate } \\
(4.8 \mathrm{~L} / \mathrm{ha})\end{array}$ & $\begin{array}{c}\text { Biscaya, } 24 \% \text { of } \\
\text { oily dispersion } \\
(0.25 \mathrm{~L} / \mathrm{ha})\end{array}$ & $\begin{array}{c}\text { Actophyte, } \\
0.25 \% \text { of } \\
\text { emulsion } \\
\text { concentrate } \\
(2.4 \mathrm{~L} / \mathrm{ha})+ \\
\text { Biscaya, } 24 \% \text { of } \\
\text { oily dispersion } \\
\text { (0.25 L/ha) }\end{array}$ & $\begin{array}{c}\text { Actophyte, } \\
0.25 \% \text { of } \\
\text { emulsion } \\
\text { concentrate } \\
(4.8 \mathrm{~L} / \mathrm{ha})+ \\
\text { Biscaya, } 24 \% \text { of } \\
\text { oily dispersion } \\
(0.25 \mathrm{~L} / \mathrm{ha})\end{array}$ \\
\hline
\end{tabular}

\begin{tabular}{|c|c|c|c|c|c|c|c|c|c|c|c|}
\hline t/ha & $\begin{array}{c}\text { Yield } \\
\text { saved, } \\
\text { t/ha }\end{array}$ & $\begin{array}{c}\text { Yield } \\
\text { capacity, }\end{array}$ & $\begin{array}{l}\text { Yield } \\
\text { saved }\end{array}$ & $\begin{array}{c}\text { Yield } \\
\text { capacity }\end{array}$ & $\begin{array}{l}\text { Yield } \\
\text { saved }\end{array}$ & $\begin{array}{l}\text { Yield } \\
\text { capacity, }\end{array}$ & $\begin{array}{l}\text { Yield } \\
\text { saved }\end{array}$ & $\begin{array}{c}\text { Yield } \\
\text { capacity, }\end{array}$ & $\begin{array}{c}\text { Yield } \\
\text { saved. }\end{array}$ & $\begin{array}{c}\text { Yield } \\
\text { capacity } \\
\text { t/ha }\end{array}$ & \\
\hline
\end{tabular}

$\begin{array}{ccccccccccccccc}2011 & 0.167 & - & 0.289 & 0.122 & 0.314 & 0.147 & 0.397 & 0.23 & 0.468 & 0.301 & 0.522 & 0.355 \\ 2012 & 0.085 & - & 0.132 & 0.047 & 0.144 & 0.059 & 0.202 & 0.117 & 0.252 & 0.167 & 0.284 & 0.199 \\ \text { Average } & 0.126 & - & 0.21 & 0.084 & 0.229 & 0.103 & 0.3 & 0.174 & 0.36 & 0.234 & 0.403 & 0.277\end{array}$

HIP05 according to research variants (factor $\mathrm{A})-0.10$

$\mathrm{HIP} 05$ according to research years (factor $\mathrm{B})-0.06$

The variants when applying the microbiological preparation Actophyte, $0.25 \%$ of emulsion concentrate at the consumption rate of 2.4 and $4.8 \mathrm{~L} /$ ha were the least effective ones. When applying the microbiological preparation Actophyte, $0.25 \%$ of emulsion concentrate at the consumption rate of $2.4 \mathrm{~L} / \mathrm{ha}$ the increase in the yield capacity of white mustard was $0.130 \mathrm{t} / \mathrm{ha}$ on the average, the increase in the yield of Chinese mustard was $0.101 \mathrm{t} / \mathrm{ha}$ and spring rape gave the increase of $0.084 \mathrm{t} / \mathrm{ha}$. At the 
consumption rate of $4.8 \mathrm{~L} /$ ha the saved yield of white mustard was $0.162 \mathrm{t} / \mathrm{ha}$, the saved yield of Chinese mustard at the level of $0.111 \mathrm{t} / \mathrm{ha}$ and the saved yield of spring rape was at the level of $0.103 \mathrm{t} / \mathrm{ha}$.

At the end of the third decade of June spring rape is in the phenophase of the pods formation and the rape blossom beetles are beginning to leave the fields but the larvae of the rape blossom beetle are still finishing feeding on the rape crops. Since there are no more flowers on the rape crops the larvae feed on the young pods and the seeds that are forming in the pods. As a result the undeveloped pods of the ugly shape are forming and the seeds are damaged by the gnawing mouths of the larvae (Fig. 8).

In 2012 after harvesting the crops of spring rape we cleaned and thoroughly analysed them and selected the seeds of spring rapes gnawed by the larvae of the rape blossom beetle as well as the healthy seeds without any signs of damage. Under the laboratory conditions a weight of 1000 both undamaged and damaged seeds and the filling, that is a number of seeds per unit of volume, were determined (Table 9).

From the data given in Table 9 it is seen that the weight of 1000 healthy seeds is $2.69 \mathrm{~g}$, and the weight of the damaged ones is $0.42 \mathrm{~g}$. So the weight of 1000 seeds damaged by the gnawing mouth of the larvae is less by $84.4 \%$ in comparison with the undamaged seeds; and the filling of the damaged seeds is 6.8 times more, which indicates their smaller size and frailness.

A)



B)



Fig. 8. Spring rape seeds, undamaged (A) and damaged by the larvae of rape blossom beetle (B) (photo by the author)

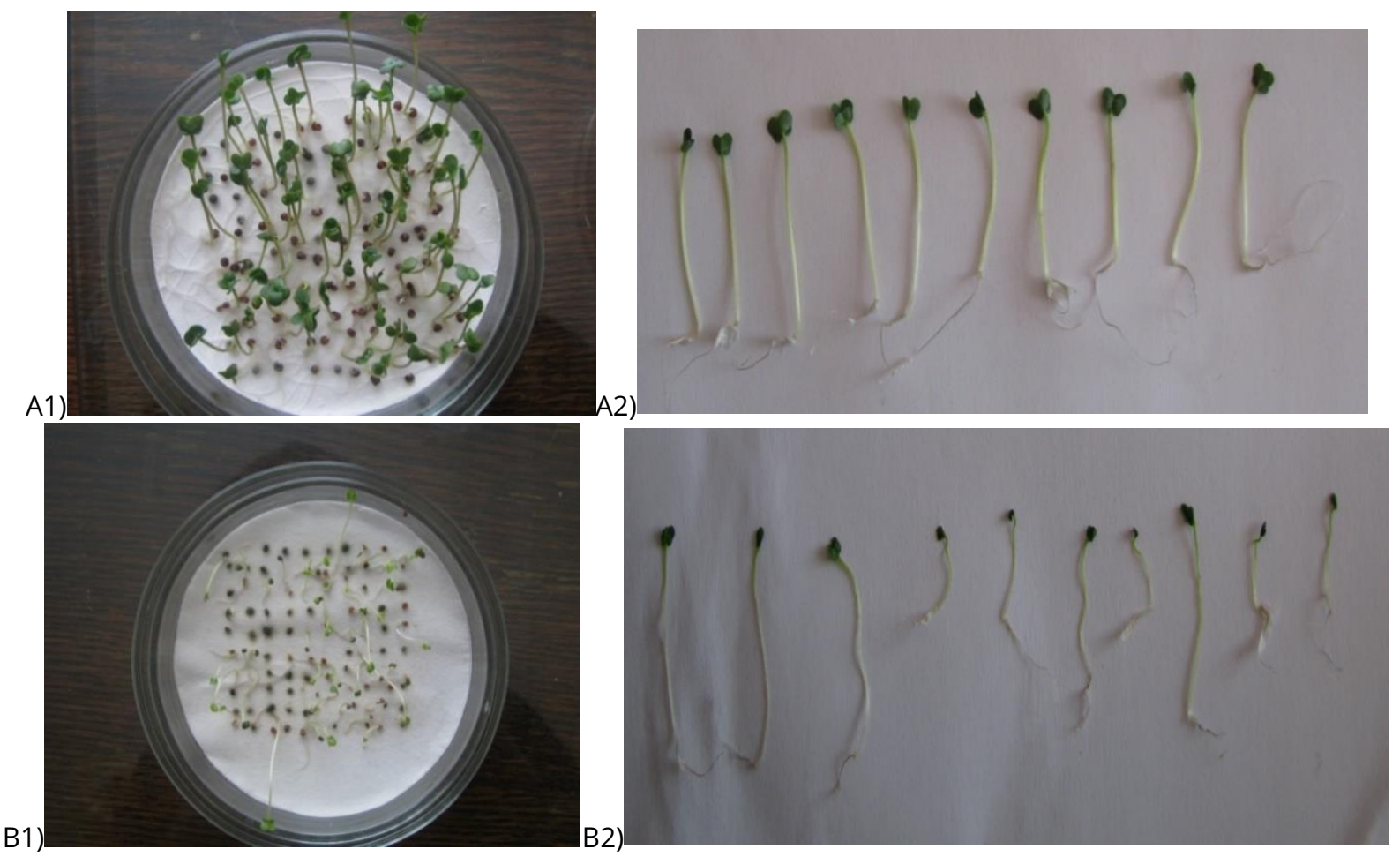

Fig. 9 Spring rape seedlings obtained at the laboratory on the 8th day from undammed seeds (A1 and A2) and from seeds damaged by the larvae of rape blossom beetle (B1 and B2) (photo by the author)

At the laboratory of the Seed Quality of the Plant Growing Institute named after V.Ya. Yuriev of the National Academy of Agrarian Sciences of Ukraine the biochemical analysis of the undamaged seeds of spring rape and the seeds damaged by the larvae of the rape blossom beetle was carried out. The mass fraction of fat was determined according to the method of Rushkovskyi and the protein content in the seeds was determined by the Kjeldahl method. 
Table 9. Influence of spring rape seeds of Ataman variety damaged by larvae of rape blossom beetle on quantitative and qualitative indices

\begin{tabular}{|c|c|c|c|c|c|c|c|c|}
\hline \multirow[b]{2}{*}{ Seed fractions } & \multicolumn{2}{|c|}{ Weight of 1000 seeds } & \multicolumn{2}{|c|}{ Filling } & \multicolumn{2}{|c|}{ Fat content } & \multicolumn{2}{|c|}{ Protein content } \\
\hline & g & $\begin{array}{c}\text { in } \% \text { to } \\
\text { undamaged }\end{array}$ & pieces $/ \mathrm{cm}^{3}$ & $\begin{array}{l}\text { in ratio to } \\
\text { undamaged }\end{array}$ & $\%$ & $\begin{array}{l}\text { in ratio to } \\
\text { undamaged }\end{array}$ & $\%$ & $\begin{array}{l}\text { in ratio to } \\
\text { undamaged }\end{array}$ \\
\hline Undamaged & 2.69 & 100.0 & 220 & 100.0 & 35.92 & - & 30.97 & - \\
\hline Damaged & 0.42 & 15.6 & 1500 & 681.8 & 17.48 & -18.44 & 32.23 & +1.26 \\
\hline HIP05 & 0.27 & & 153.92 & & 5.46 & & 9.91 & \\
\hline
\end{tabular}

From the data given in Table 9 it is seen that the undamaged seeds of spring rape contain $35.92 \%$ of fat, and the damaged seeds contain only $17.48 \%$ of fat, that is 2.05 times less. The protein content in the undammed seeds was $30.97 \%$ and in the damaged ones it was $32.23 \%$, that is 1.04 times more. The data of biochemical analysis indicate that the larvae of the rape blossom beetle first of all gnaw out those parts of the seeds that contain the fat substances.

As a result of the germination of spring rape seeds under the laboratory conditions the influence of the seeds damaged by the larvae of the rape blossom beetle on the laboratory germination was established (Table 10).

From the data given in Table 10 it is seen that on the first day after sowing no germination was observed in any variant. On the second day the germination rate of the undamaged seeds was $6.3 \%$ and that of the damaged seeds was 0 ; on the third day the germination rate of the undamaged spring rape seeds was $74.2 \%$ vs. $15.8 \%$ in the variant with the damaged seeds. The seed germination on the fourth day after sowing was $8.0 \%$ for the undamaged seeds and $33.3 \%$ for the damaged ones. On the fifth day after sowing the germination rate of the undamaged seeds was $87.3 \%$ and that of the damaged ones was $47.0 \%$. On the sixth day after sowing the germination rate of the undamaged seeds was $89.3 \%$ vs. $54.3 \%$ of the damaged ones. On the seventh day after sowing the laboratory germination of the undamaged spring rape seeds was $90.0 \%$ vs. $56.7 \%$ of the damaged ones. The final germination of spring rape seeds under the laboratory conditions was recorded on the eighth day because no new germinated seeds were observed. For the undamaged spring rape seeds it was $90.0 \%$ and for the damaged seeds it was $58.0 \%$, that is by $32.0 \%$ lower (Fig. 9).

Table 10. Influence of spring rape seeds of Ataman variety damaged by the larvae of rape blossom beetle on the laboratory germination

\begin{tabular}{|c|c|c|c|}
\hline Day of research & undamaged & $\begin{array}{l}\text { germinatic } \\
\text { damaged }\end{array}$ & in ratio to undamaged \\
\hline first & 0 & 0 & - \\
\hline second & 6.3 & 0 & -6.3 \\
\hline third & 74.2 & 15.8 & -58.4 \\
\hline fourth & 86.0 & 33.3 & -52.7 \\
\hline fifth & 87.3 & 47.0 & -40.3 \\
\hline sixth & 89.3 & 54.3 & -35.6 \\
\hline seventh & 90.0 & 56.7 & -33.3 \\
\hline eighth & 90.0 & 58.0 & -32.0 \\
\hline HIP05 & & 17.02 & \\
\hline
\end{tabular}

Fig. 9 shows that when germinating the spring rape seeds under the laboratory conditions the seedlings obtained from the undamaged seeds are much more developed, have a healthy dark green colour; and the seedlings obtained from the damaged seeds are weak, have a thin stem and the cotyledons of light greenish colour.

\section{Conclusions}

In the Eastern Forest-Steppe of Ukraine the first individuals of the rape blossom beetle appear on the flowering wild growing plants (first of all on dandelion and buttercup) when the average daily temperature exceeds $8{ }^{\circ} \mathrm{C}$, it is the middle of the first decade of April and the beginning of the third decade of April. The mass emergence of the rape blossom beetles takes place when the daily average temperatures are at the range of $9-13^{\circ} \mathrm{C}$ and the sum of the effective temperatures above $5{ }^{\circ} \mathrm{C}$ is at 
the range of $100-113^{\circ} \mathrm{C}$, it is the middle of the second decade of April and the end of the third decade of April. The females of the rape blossom beetle usually lay 2-3 eggs into one bud of spring rape or mustard.

When protecting the crops from the rape blossom beetle the highest technical efficiency was noted when applying the binary mixture of the microbiological preparation Actophyte, $0.25 \%$ of emulsion concentrate in the dose of $4,8 \mathrm{~L}$ ha-1 and systemic insecticide Biscaya, $24 \%$ of oily dispersion ( $0.25 \mathrm{~L} \mathrm{ha}^{-1}$ ) and in 14 days after spraying it was $77 \%$ on white mustard, $74 \%$ on Chinese mustard and $76 \%$ on spring rape. The highest growth increase in the yield capacity was observed in the same variant; for white mustard it was $0.43 \mathrm{t} \mathrm{ha}^{-1}$, for Chinese mustard it was $0.27 \mathrm{t} \mathrm{ha}^{-1}$ and for spring rape the growth increase amounted to $0.28 \mathrm{t} \mathrm{ha}^{-1}$.

It is established that the weight of 1000 healthy seeds is $2.70 \mathrm{~g}$, and the weight of seeds damaged by the larvae of the rape blossom beetle is $0.42 \mathrm{~g}$, so it is reduced by $84 \%$. The filling of the damaged seeds is 6.8 times higher, which indicates that they are smaller in diameter and frail. The undamaged seeds of spring rape contain $36 \%$ of fat, and the damaged seeds contain only $18 \%$, which is 2.1 times less. The protein content in the undamaged seeds was $31 \%$ and in the damaged ones it was $32 \%$, that is 1.0 times more. The germination rate of the undamaged seeds of spring rape under the laboratory conditions on the eighth day was $90 \%$, and the germination rate of the damaged ones amounted to $58 \%$ and was lower by $32 \%$.

\section{References}

Andersen A., Kjos O., Nordhus E., Johansen N. S. (2008). Resistens mot pyretroider hos rapsglansbille - hva na? Plantemotet, 3 (1), 94-95.

Beleckij E. N. \& Stankevich S. V. (2018). Policiklichnost', sinhronnost' i nelinejnost' populjacionnoj dinamiki nasekomyh i problemy prognozirovanija, Vienna, Premier Publishing s.r.o. Vienna, 138. (in Russian).

Beleckij E. N., Stankevich S. V. \& Nemerickaja L. V. (2017). Sovremennye predstavlenija o dinamike populjacij nasekomyh: proshloe, nastojashhee, budushhee. Sinergeticheskij podhod. Vesti HNAU im. V. V. Dokuchaeva. Ser. «Fitopatologija i jentomologija», vv. 1-2, 22-33. (in Russian).

Evtushenko N.D, Stankevich S.V. (2012). Sezonnaya dinamika chislennosti rapsovogo cvetoeda, Meligethes aeneus (F., 1775) (Coleoptera: Nitidulidae) na yarovom rapse i gorchice $v$ Harkovskom rajone Izvestiya Harkovskogo entomologicheskogo obshestva, T. XX. Vyp. 2, 65-68. (in Russian).

Fedorenko V. P., Sekun N.P., Markov I.L. i dr. (2008). Zashita rapsa. Zashita i karantin rastenij, 3, 69-93.

Golovan L.V., Klymenko I.V., Stankevych S.V., Vasylieva Yu.V., Chupryna Yu.Yu., Zabrodina I.V., Zhukova L.V., Nazarenko V.V., Belay Yu.M. (2019). The inheritance of economically valuable features in the intraspecific hybridization of bean (Phaseolus L). Ukrainian journal of ecology, 9 (2), 156-169.

Gorodnij M. G. (1970). Olijni ta efiroolijni kulturi. Kiyiv, Urozhaj, 276.

Gurova Z. I. (1963). Vrediteli semennikov ovoshnyh krestocvetnyh kultur rajona vostochnoj chasti Lesostepi Ukrainy i mery borby s nimi: avtoref. dis. kand. biol. nauk. Harkov, 24.

Kovalchuk G. M. (1987). Ripak ozimij - cinna olijna i kormova kultura. Kiyiv, Urozhaj, 112.

Kozhanchikov I. V. (1929). K biologii Meligethus aeneus Fabr. Zashita rastenij ot vreditelej. Byull. Byuro Vserossijskih entomofitopatologicheskih sezdovov. Leningrad, Izd-vo zashita rastenij ot vreditelej, 560-562.

Metodika uchyota i prognoza razvitiya vredietelej i boleznej polevyh kultur v Centralno-Chernozyomnoj polose. Izd. 2-e, ispr. i dop. (1976). Voronezh, Centralno-chernozyomnoe kn. izd., 136. (in Russian).

O vrednyh nasekomyh (1845). Izdano uchyonym komitetom ministerstva gosudarstvennyh imushestv. Sankt-Peterburg, Tipografiya Ministerstva Gosimushestv, 278.

Orobchenko V. P. (1959). Raps ozimyj. Moskva, Selhozgiz, 160.

Osmolovskij G. E. (1972). Vrediteli kapusty. Leningrad, Kolos, 79.

Rekomendacii po obsledovaniyu selskohozyajstvennyh ugodij na zaselyonnost vreditelyami i zaselyonnost boleznyami (1975). Kiev, Urozhaj, 60. (in Russian).

Saharov N. L. (1934). Vrediteli gorchicy i borba s nimi. Saratov, Saratovskoe kraevoe gos. izd-vo, 120.

Shpaar D. (2007). Chrezvychajnaya situaciya s rapsovym cvetoedom v Evrope. Zashita i karantin rastenij, 12, $26-27$.

Stankevich S.V. \& Zabrodina I.V. (2016). Ekonomichni porogi shkidlivosti osnovnih shkidnikiv silskogospodarskih kultur, Harkiv, HNAU, 24. (in Ukrainian).

Stankevich S.V. \& Zabrodina I.V. (2016). Monitoring shkidnikiv silskogospodarskih kultur, Harkiv, FOP Brovin O.V., 216. (in Ukrainian).

Stankevich S.V. (2012). Rasteniya-rezervatory vreditelej maslichnyh krestocvetnyh kultur. Byuleten nauchnyh rabot BelSHA, 32, 22-32. (in Russian).

Stankevich S.V. (2012). Zastosuvannya mikrobiopreparatu aktofit v poyednanni z insekticidom biskajya proti ripakovogo kvitkoyidu u fenofazu zhovtogo butonu. Visnik HNAU im. V. V. Dokuchayeva. Ser. "Fitopatologiya ta entomologiya", 12, 115-122. (in Ukrainian).

Stankevich S.V. (2014).Yakisni pokazniki nasinnya ripaku yarogo zalezhno vid protruyuvannya ta poshkodzhennya lichinkami ripakovogo kvitkoyida. Visnik HNAU im. V. V. Dokuchayeva. Ser. "Fitopatologiya ta entomologiya", 8, 114-120. (in Ukrainian).

Stankevich S.V. (2015).Sezonnaya dinamika chislennosti rapsovogo cvetoeda na yarovom rapse i gorchice v vostochnoj lesostepi Ukrainy. Zashita rastenij. Sbornik nauchnyh trudov, 39, 197-203. (in Russian). 
Stankevich S.V. (2018). Zmina paradigmi u zahisti olijnih kapustyanih kultur vid ripakovogo kvitkoyida za ostanni 140 rokiv. Visnik HNAU im. V.V. Dokuchayeva. Ser. "Fitopatologiya ta entomologiya", 1-2, 127-145. (in Ukrainian).

Stankevich S.V., Beleckij E.N. \& Zabrodina I.V. (2019). Ciklicheski-nelinejnaya dinamika prirodnyh sistem i problemy prognozirovaniya. Vankuver, Accent Graphics Communications \& Publishing. Vankuver, 232. (in Russian).

Stankevych S.V., Vasylieva Yu.V., Golovan L.V., Zabrodina I.V., Lutytska N.V., Nakonechna Yu.O., Molchanova O.A., Chupryna Yu.Yu., Zhukova L.V. (2019). Chronicle of insect pests massive reproduction. Ukrainian Journal of Ecology, 9 (1), $262-274$.

Stankevych S.V., Yevtushenko M.D., Zabrodina I.V., Biletskiy Ye.M., Baidyk H.V., Lezhenina I.P., VasylievaYu.V., Filatov M.O., Sirous L.Ya. V.V. Dokuchaiev Scientific school of Kharkiv National Agrarian University and development agricultural entomology in XIX-XXI centuries. (2019). Ukrainian journal of ecology, 9 (2), 170-178.

Tribel S. O. et al. (2001). Metodiki viprobuvannya i zastosuvannya pesticidiv, Kiyiv, Svit, 448. (in Ukrainian).

Turenko V.P., Bilyk M.O., Zhukova L.V., Stankevych S.V., Zayarna O.Yu., Lukhanin I.V., Oleynikov Ye.S., Batova O.M., Goryainova V.V., PoedincevaA.A. (2019). Pathogens of spring barley on abiotic factors in the eastern forest - steppe of Ukraine Ukrainian journal of ecology, 9 (2), 179-188.

Wivstad M. (2010). Klimatforandringarna - en utmaning for jordbruket och Giftfri miljo. Uppsala: Kemikalieinspektionen, 94.

Yevtushenko N.D, Stankevich S.V. (2011). Roslini-rezervatori osnovnih shkidnikiv olijnih kapustyanih kultur. Visti Harkivskogo entomologichnogo tovaristva, T. XIX, Vyp. 2, 71-76.

Yevtushenko M. D., Stankevich S.V. \& Vilna V.V. (2014). Hrestocviti blishki, ripakovij kvitkoyid na ripaku yaromu j girchici u Shidnomu Lisostepu Ukrayini, Harkiv, 170. (in Ukrainian).

Yevtushenko M. D., Vilna V. V. \& Stankevich S. V. (2016).Hrestocviti klopi na ripaku yaromu j girchici u Shidnomu Lisostepu Ukrayini, Harkiv, FOP Brovin O.V., 184. (in Ukrainian).

Yevtushenko N.D, Stankevich S.V. (2011). Roslini-rezervatori osnovnih shkidnikiv olijnih kapustyanih kultur. Visti Harkivskogo entomologichnogo tovaristva. T. XIX. Vip. 2, 71-76. (in Ukrainian).

Zhukova L.V., Stankevych S.V., Turenko V.P., Bezpal'ko V.V., Zabrodina I.V., Bondarenko S.V., Poedinceva A.A., Golovan L.V., Klymenko I.V., Melenti V.O. (2019). Root rots of spring barley, their harmfulness and the basic effective protection measures Ukrainian journal of ecology, 9 (2), 232-238.

\section{Citation:}

S. V. Stankevych, M. D. Yevtushenko, V. V. Vilna, I. V. Zabrodina, D. D. Yushchuk et al. (2019). Efficiency of chemical protection of spring rape and mustard from rape blossom beetle. Ukrainian Journal of Ecology, 9(4), 584-598 